\title{
LIFELONG LEARNING AND EMPLOYABILITY - THE ROLE OF NON-FORMAL EDUCATION
}

\begin{abstract}
The aim of this paper it to examine the relationship between non-formal education and employability within the context of socio-cultural changes. This paper presents the analysis of the effects of non-formal learning activities that are conducted at the Croatian Employment Service in the form of workshops, with an aim of raising employability among unemployed people. The participants in this research were unemployed persons who attended workshops at the Regional Office of the Croatian Employment Service Zadar during the year 2013. This survey focuses on evaluation of effects of non-formal learning through workshops within groups of unemployed persons, depending on their age, gender and level of education. As the forms of non-formal education indicate organized learning activities with the aim of acquiring and improving knowledge, skills and competences for personal, social and professional needs, the aim of this study is to define the role of non-formal education as a positive aspect of employability or set of knowledge, expertise and ability of a person. The results of attending the workshops can potentially include retaining one's job, career progress, obtaining a new job and assuring the entrance to the labour market in different periods of the working life cycle.
\end{abstract}

Keywords: non-formal education, employability, unemployment, community, lifelong learning.

\section{VSEŽIVLJENISKO UČENJE IN ZAPOSLJIVOST - VLOGA NEFORMALNE IZ- OBRAZBE - POVZETEK}

Prispevek obravnava razmerje med neformalno izobrazbo in zaposljivostjo znotraj konteksta sociokulturnih sprememb. Predstavljena je analiza učinkov neformalnih učnih aktivnosti, ki se izvajajo na hrvaškem zavodu za zaposlovanje v obliki delavnic, s ciljem povečati zaposljivost med nezaposlenimi posamezniki. V raziskavi so sodelovali nezaposleni, ki so se udeležili delavnic regijske izpostave zavoda v Zadru v letu 2013. Raziskava se osredotoča na evalvacijo učinkov neformalnega izobraževanja s pomočjo delavnic znotraj skupin nezaposlenih posameznikov glede na njihovo starost, spol in stopnjo izobrazbe. Ker oblike neformalnega izobraževanja predstavljajo organizirane učne aktivnosti s ciljem pridobivanja in izboljševanja znanja, spretnosti in kompetenc, potrebnih v zasebnem, družbenem in profesionalnem udejstvovanju, je cilj študije definirati vlogo neformalnega izobraževanja kot pozitivnega vidika zaposljivosti, kompleta znanja, strokovnosti ali sposobnosti posameznika. Rezultati

Ph.D. Višnja Perin, Croatian Employment Service, Regional Office Zadar, visnja.perin@hzz.hr

Ph. D. Matilda Karamatić Brčić, University of Zadar, Department of Education, mkarama@unizd.hr 
udeležbe na delavnicah lahko posamezniku potencialno pomagajo, da obdrži službo oz. pridobi novo, mu omogočajo karierni napredek in zagotavljajo vstop na trg dela v različnih obdobjih delovnega življenjskega cikla.

Ključne besede: neformalno izobraževanje, zaposljivost, nezaposlenost, skupnost, vseživljenjsko učenje

\section{LIFELONG LEARNING}

Lifelong learning indicates all learning activities undertaken by an individual during his life, and which result in improving the knowledge, skills, competences and/or qualifications for personal, social and/or professional reasons (Razvoj politike cjeloživotnog profesionalnog usmjeravanja, 2013, p. 11). Since lifelong learning means education throughout schooling, and even later through various forms of non-formal education by means of courses, additional training or retraining and professional development, it represents the process of constant upgrades and increase of knowledge acquired in the formal school system in order to improve the existing capabilities and acquire new skills and modern qualifications. In the nineties of the last century lifelong learning was established in Europe as a policy that responds to the problems of economic crisis and increased unemployment (Žiljak, 2005). During this period, the focus was shifting from education, which is an institutionalized and organized process, to lifelong learning, which includes all forms of education in all life circumstances. In this paper the education is viewed as a process of acquiring knowledge, skills and habits, and represents a dynamic activity that provides a continuous relationship with the changes occurring in the socio-cultural context. Thereby, education becomes the image of society as a whole, and the need for development of different forms of education is a response to requests of the same. There are three basic forms of education within upbringing and educational systems of European countries: formal, non-formal and informal education. Formal education refers to education carried through the institutional education training, which is a part of the formal system of education of certain country. According to Jurić (2007, p. 72), formal education includes a hierarchical structure of the school system from primary to tertiary level and organizationally develops school curricula which imitate and simulate situations that can be found in the world of work and production. Non-formal education is a form of education which involves non-institutional educational activities aimed at developing specific competences required for living and working. Informal education includes various forms of acquiring competences through self-education, whereby the result is the expansion of existing knowledge in the context of lifelong learning. Jurić (2007, p. 69) says that informal education usually occurs at a certain age, after regular schooling, and is usually linked to lifelong education, which follows the institutional education. In the context of contemporary views on the education the three mentioned forms of educational activities together constitute a whole which is called the concept of Lifelong Learning. Since a significant segment of this research relates to the non-formal education, the attention will be given exactly to that form of educational activities, in order to define its contribution to a possible easier employability. During the past 40 years lifelong learning developed from the initial idea to a dominant principle and orientation of the development 
of many national education systems. Its importance is pointed out in a number of international action plans, declarations, documents and conferences (Memorandum on Life Long Learning, 2000). The term education is multifaceted with regard to the socio-cultural context in which it is defined. For example, in Anglo-Saxon countries the concept of education is defined together with the upbringing through the term education (Mialaret, 1989), while in countries of Central Europe upbringing and education have different definitions (Peko, 1999, p. 205). Education as a social and historical category indicates the process that is focused on continuous learning, whereby an individual strengthens his or hers abilities. It contributes to forming a view of the world and builds foundations for the permanent connection of knowledge, skills and abilities within the school system and beyond.

\section{NON-FORMAL EDUCATION}

Non-formal education can be defined as an organized teaching and learning which is more or less didactically devised, and by which an individual acquires some other knowledge or skills, adopts and meets the supplemental, additional or alternative learning needs. UNESCO'S definition of non-formal education from 1972 reduced the term non-formal education to an organized educational activity outside the formal system, which has the purpose to satisfy the needs of users but also meet the learning objectives. Contemporary authors emphasize that the non-formal education is an organized and systematic activity which allows individuals to acquire and improve their knowledge, skills and competences for personal, social and professional needs. Education, according to Gudjons (1994, p. 162), represents training for reasonable self-determination, productive participation in culture, achieving individuality and sociality and versatility in moral, cognitive, aesthetic and practical dimensions. If we look back at the broader view of education through non-formal education, we can observe that existing knowledge and skills acquired through formal education are usually extended and augmented, while knowledge and skills which one did not acquire during the formal education are also obtained. Non-formal education is intended for diverse groups of people, from children and young people who are still in the formal education system, through adults of working age, to elderly persons. Acording to Marković (2005), non-formal education determines the educational activities that are organized and planned and also encourage individual to engage in social learning. It is obvious that non-formal education is more widespread and contemporary type of learning and that it has become indispensable in modern life and work practices. Education and professional improvement, especially non-formal education, are now considered a requirement for survival, further development and for obtaining a perspective of modern society. The Copenhagen Declaration (2002) states that strategies for lifelong learning and mobility are crucial for promoting employability, active citizenship, social inclusion and personal development of every individual. According to Previšić (2007, p. 185), in today's era of rapid changes only the quality of general education can ensure a secure foundation for the upgrade of constant innovation and new knowledge. The author emphasizes that a permanent and global education have become a new educational assignments that need to be articulated in the system long life 
learning. Our opinion is that quality mandatory education in a given country represents a basis for quality and structured higher education within the formal upbringing-educational system. Furthermore, the quality of formal upbringing and education enables an individual to actively and thoughtfully participate in lifelong learning through targeted selection of adequate and focused forms of non-formal education for improvement of existing competencies as well as the acquisition of new competencies required for better life and work.

\section{UNEMPLOYMENT, EMPLOYABILITY AND LIFELONG LEARNING}

Completion of schooling and training for a certain profession, i.e. the acquisition of a particular title or profession, does not necessary represent a finalization, since a modern labour market includes new challenges and demands of seeking continuous improvement and acquisition of new knowledge and skills according to today's needs of the broader community. Europe 2020 Strategy (2010) provides a vision of Europe's social market economy for the 21 st century. Within the same, three priorities that complement each other are proposed: smart growth (developing an economy based on knowledge and innovation); sustainable growth (promoting an economy that effectively leverages resources, that is greener and more competitive); and inclusive growth (fostering an economy with high employment that delivers social and territorial cohesion). Among the major challenges of modern European labour markets, we can identify, among other things, the increased growth of demand for transversal competences and competences that can be applied in different business and life situations; and flexicurity, as a strategy that includes a new approach to workplace and employment and implies switching from "safe workplace" to "secure employability". International Labour Organization (ILO, 2002) defines employability as a set of knowledge, expertise and person's ability to gain and retain work, career progress, to find another job if a person was fired or enters the labour market in different periods of his or hers life cycle. The search for different education indicates that there is hope for the better. The starting point of such search is the idea of education as a process of cultural reconstruction, social integration (socialization) and individualization, and the importance of education in promoting cognitive, moral - practical and expressive - aesthetic (Vrcelj, 2007, p. 486). Continued education as a response to the demands of modern society becomes the duty of every individual in order to better his or hers copayment as well as increase his or hers employability in the same society. Employability refers not only to the professional and academic skills of the individual. Of equal importance to the individuals is the appropriate and meaningful information from the labour market in order for them to be able to make informed decisions about alternatives and opportunities which they are offered in the same market. They may also require aid in discerning of when such information can be useful, as well as interpreting such information and converting it into usable knowledge. We can say that the individual's employability depends on social and cultural capital, i.e. knowledge, skills and attitudes possessed; followed by the ability to employ all of the above and the way in which a person is able to present him- or herself in the labour market and the knowledge and understanding of the context within the labour market. 


\section{RESEARCH METHODOLOGY}

Since forms of non-formal education include organized learning activities aimed at acquiring and improving knowledge, skills and competences for personal, social and professional needs, as well as the problem of this research, the question arises as to whether the non-formal education affects the employability of individuals, whereby we observed the employability through employment within six months of attending the workshop. The aim of the research is to evaluate the effects of non-formal learning through workshops on the situation of unemployed persons in relation to their age, sex, completed education and length of unemployment before joining the workshop. We proceed from the hypothesis that the individuals who are included in the workshop will be faster and more often hired than individuals who were instructed to the same, but objected to attend the workshops. It is our opinion that the inclusion in workshops will have a greater effect with individuals that were included in the workshop immediately after becoming unemployed, since most of the research on unemployed individuals shows that early interventions are the most efficient.

The research was conducted with individuals who were sent to workshops at the Branch office of the Croatian Employment Service Zadar during 2013 ( $N=313$ ). Proceeding from these hypotheses the tasks mentioned below were established:

Tasks:

- To examine the structure of the individuals sent to workshops (age, sex, educational attainment, length of unemployment).

- To discern whether there is a difference in employability between the individuals involved in the workshops and those that are addressed, but were not included.

- To check whether there is a difference in employability between the individuals involved in workshops, related to age, gender, educational attainment and length of unemployment.

\section{Methods}

The data on unemployed persons (age, sex, educational attainment, length of unemployment before joining the workshop and employment after attending a workshop within six months) addressed in workshops "How to Find Work" and "Presenting Yourself to the Employer", conducted by Croatian Employment Service regional office in Zadar during $2013^{1 \text {, will be }}$ collected from the database of the Croatian Employment Service Regional Office Zadar.

The data collected will be analyzed by employing descriptive statistics and using appropriate statistical methods.

1 Through the workshop "How to look for a job," the unemployed individuals are being prepared for an active job search through the acquisition of knowledge and skills required to identify and search for job vacancies in accordance with their competencies, while also practicing how to write resumes and cover letters. Through the workshop "How to present yourself to the Employer ", the unemployed individuals are being prepared for a job interview, acquiring knowledge and skills required in preparation for an interview. Workshops are held once a week and each workshop lasts 90 minutes. Unemployed individuals who are have participated in the workshops also indicate their counsellors in employment mediation. 


\section{RESULTS AND DISCUSSION}

Altogether during 2013, 313 candidates were sent to the workshop "Looking for a Job" and "How to present yourself to the employer". Out of that number, $68.37 \%$ of people attended the workshops.

The percentage of men who were sent to the workshop (55.3\%) was higher than that of women (44.7\%). When we look at the response to the workshops, women are slightly more inclined to take part in the workshops than men (Yates $\chi 2=3.62, \mathrm{p}=0.0572, \mathrm{df}=1$ ). Out of the total number of people who have been sent to the workshops, $74.3 \%$ of women and $63.6 \%$ of men responded positively.

The average age of the candidates sent to the workshops was 25 years, and the age range varied from 17 to 57 years. The highest number of referrals was up to the age of $20(46 \%)$, followed by individuals between 21 and 25 years of age (25\%), individuals between 26 and 35 (15\%) and individuals older than 36 years. Most individuals who responded to the workshops are older than 36 years $(84.1 \%)$, followed by individuals between 21 to 25 years of age (69.2\%), individuals up to 20 years of age (65.3\%), and individuals between 26 and 35 years of age (61.7\%). Although the difference between age groups was not statistically significant (Yates' $\chi 2=5.006, \mathrm{p}=0.1714, \mathrm{df}=3$ ) we can observe that older respondents were more likely to respond to non-formal education than younger ones. This can be explained by them possessing greater life experience which familiarized them with the benefits they can obtain from various forms of education and learning, including non-formal learning. We believe that this result could indicate the importance of lifelong learning.

Most individuals who attended the workshops had finished secondary school. $44 \%$ of referrals finished secondary school in four years, $39 \%$ of referrals attended secondary school lasting 3 years, $11 \%$ of referrals attended elementary school was, and $6 \%$ possessed tertiary education. There is a statistically significant difference in response to the workshops related to previous completion of school (Yates' $2=11.16, p=0.0108$, $\mathrm{df}=3$ ). The workshops were attended mostly by individuals who had completed higher education $(77.8 \%)$, followed by those who have finished high school in three years duration (73.8\%) and high school in four years duration (68,8\%). The lowest response was recorded with individuals who finished elementary school, i.e. the lowest level of education, $(42.9 \%)$. We can therefore observe that when a person has more formal education, he or she is more aware of the importance of learning and of the benefits one can receive from various forms of non-formal education and learning.

The largest number of referrals had been registered as unemployed more than one and less than three months (68\%), followed by those who were sent to the workshops immediately or within the first month of their registration as unemployed (14\%), followed by those who had been long- term unemployed or unemployed for over a year (8\%), individuals who had been unemployed between 6 months and one year (7\%), and lastly the individuals who had been registered as unemployed between 3 and 6 
months (3\%). Regarding the length of previous unemployment and responsiveness to the workshops there was no significant difference between the groups. Individuals who were referred to the workshops immediately responded in $75.6 \%$ of the cases, those unemployed for up to 3 months in $66.7 \%$ of the cases, unemployed 3-6 months $70 \%$, those unemployed over 12 months $75 \%$ and the individuals who had been unemployed between 6 and 12 months in 52.5\% We can observe that individuals who responded to the workshops the least are those who had been unemployed for between 6 and 12 months, which can be explained with the Harrison cycle of unemployment (Tržište rada i zapošljavanje, 2003). He described the psychological state of the unemployed after losing their jobs in four phases. 1. Shock: Phase of shock starts when an individual finds out that he or she is losing his or her jobs and is of relatively short duration. The stage of shock is dominated by strong feelings: mixed anger and disappointment. Because of the intense emotions, an individual at this stage usually fails to think soberly, and also fails to plan and seek employment as well as fails to find the way out of such situation. 2. Optimism: When a person comes to his senses after the first shock has passed, the phase of optimism starts. One believes that unemployment is a problem that can be solved. One most often searches intensely for employment opportunities. He or she realizes that he or she more time available and takes advantage of that by participating in activities for which he or she did not have time before. 3. Pessimism: After a certain period, the individual "gets tired" of the incessant job search. In fact, a lot of applications were written, interviews were done, but without any results. These small failures are aggregated so that an individual is slowly losing optimism and willingness to look for work. He or she realizes that it is hard to find a job, and soon significant financial problems occur, because of which the activities or hobbies that require funding must be omitted. The consequence is a reduction of social activities. 4. Apathy: The period of apathy appears after approximately six months (providing employment has not been found in the meantime). The perception of oneself is already disrupted. The individual believes that something is wrong with him or her, that he or she is less capable etc. The individual has lost a part of his or her social contacts, in some cases even most of them. After the unsuccessful search for a new job the individual is at a loss of how to achieve that goal. Negative responses received from employers negatively affect his or hers self- esteem, which prompts the establishment of a defence mechanism. The intensity of the duration of each phase, as well as the transition from one phase to another differs among individuals according to various factors of mentioned processes. Rationalizations such as: „I'm too old“, „I'm too young“, ,there is no employer that would employ in my field“, „they are not looking for people with my profession“, ,is there anything else new that can be learnt" etc. appear. These mechanisms allow an individual to accept the situation. From the total number of persons who were referred to the workshops, within six months of the completion, $30.03 \%$ of have been employed. 
Table 1: Distribution of individuals who are employed within 6 months of completion of a workshop, according to participation or non-participation in workshops

\begin{tabular}{|l|l|l|l|}
\cline { 2 - 4 } \multicolumn{1}{c|}{} & Unemployed & Employed & Total \\
\hline Did not attend workshops & 78 & 21 & $99(31.63 \%)$ \\
\hline Attended workshops & 141 & 73 & $214(68.37 \%)$ \\
\hline Total & $219(69.97)$ & $94(30.03 \%)$ & $313(100 \%)$ \\
\hline $\begin{array}{l}\text { Yates' } \chi^{2}=4.764, d f=1, \\
p=0.02906\end{array}$ & & & \\
\hline
\end{tabular}

There is a statistically significant difference in employment within 6 months between people have participated in the workshops and those that were directed to, but have not participated. People who have participated in the workshops are more employable or significantly more likely to find employment.

Taking into the account only the individuals who had participated in the workshops, there was no statistically significant difference in employment regarding gender (Yates' $\chi 2=2,1, \mathrm{p}=0,1473, \mathrm{df}=1$ ), age (Yates' $\chi 2=6,955, \mathrm{p}=0,07335, \mathrm{df}=3$ ), completed education (Yates' $\chi 2=5,173, \mathrm{p}=0,1596, \mathrm{df}=3$ ) and the duration of unemployment before inclusion in the workshops.

Table 2: Showing the connection between observed characteristics of the unemployed and employability employment after 6 months (Kendall Tau correlation coefficients)

\begin{tabular}{|l|l|}
\hline Kendall Tau correlation coefficients & Characteristics \\
\hline$-0.119^{*}$ & age \\
\hline $0.097^{*}$ & sex \\
\hline-0.037 & profession / completed school \\
\hline$-0.108^{*}$ & length of unemployment \\
\hline $0.131^{*}$ & participation in the workshop \\
\hline & ${ }^{*} p<0.05$ \\
\hline
\end{tabular}

Observing the variables referring to the unemployed individuals sent to workshops, we find the highest positive correlation between the variables of attendance and employment with people who participated in the workshop being employed more often, which confirms our hypothesis. The reason for this, apart from learning, may be that people who choose to participate in workshops usually express higher level of proactivity while seeking for a job. Positive correlation was also observed with variables of gender, meaning that women are slightly more likely to be employed than men. The reason could also be found in greater level of proactivity; they are also more frequently included in the workshops. A significant negative correlation is observed regarding the variables of age, with younger respondents being employed more often than older, although the older ones are 
more proactive and more often participate in the workshops. We believe that the labour market gives preference to the younger job seekers, while younger individuals also decide more easily to accept employment (as well as terminate it) and give less thought to various aspects and conditions of work than older persons. A negative correlation is present with variables of duration of unemployment before the inclusion in the workshops. This is consistent with Harrison's cycle of unemployment, as well as with the emphasising of the need for an early intervention in the labor market (Kerovec, 1997). The workshops have best results with people who have been unemployed for more than one and less than three months. The results were less successful with people who have been unemployed for up to a month and those who have been without work for more than 12 months.

\section{CONCLUSION}

Since the forms of non-formal education are indispensable elements of the lifelong learning process, which is focused on the acquisition and upgrading of professional knowledge, skills and abilities, the need for motivating people to participate in various forms of non-formal learning has become a reaction to the demands of modern societies, upbringing and educational systems. In this paper we analyzed the effects of certain forms of non-formal education and learning that were performed at the Croatian Employment Service in the form of workshops aimed at raising the employability of unemployed persons. Non-formal education was presented in the context of this paper as a factor in better and easier employability in today's society. The paper proceeded from the hypothesis (which has asloe been confirmed) that individuals who were referred to and included in the workshops will find work more often and faster than a individuals who were referred to the workshops, but did not attend them. The titles of the workshops were: "How to Find Work" and "Presenting Yourself to the Employer". From a total of 313 candidates referred to the workshops during the year 2013, only $68.37 \%$ attended them. While men $(55.3 \%)$ than women $(44.7 \%)$ were referred to the workshops, women were less likely to respond by attending. From the total number of individuals referred to the workshops, $74.3 \%$ of women and $63.6 \%$ of men responded. The average age of referred candidates was 25 years while the age range was from 17 to 57 years of age. We find it interesting that older respondents were more likely to respond to non-formal education workshops than younger ones, which demonstrates the higher level of awareness among older people about the importance of non-formal education. Research has shown that most of the individuals referred to workshops had finished high school, whereas only $6 \%$ of those referred possessed higher education. This was not unexpected if we consider the content of the workshops which were aimed at individuals with the primary and secondary education. Proceeding from the results of the research, we believe that the participation in the workshops that were a part of the study had best results with individuals who had been unemployed for more than one and less than three months. The forms of non-formal education are indispensable parts of the lifelong learning process which focuses on the acquisition and upgrading 
of professional knowledge, skills and abilities. Non-formal education is becoming increasingly sought after and valued in the modern world and has become a critical factor in achieving success and competitive advantage in the labour market, which has also been confirmed by the results of this research.

\section{REFERENCES}

Copenhagen Declaration. (2002). Retrieved from www.asoo.hr/UserDocsImages/dokumenti/kopenhaska_deklaracija.pdf.

Europe 2020. A strategy for smart, sustainable and inclusive growth. (2010). Retrieved from www.mobilnost.hr/prilozi/05_1300804774_Europa_2020.pdf.

Gudjons, H. (1994). Pedagogija - temeljna znanja. Zagreb: Educa.

International Labour Office (ILO) (2002). Key indicators of the Labour Market 2001-2002. Geneva: International Labour Office.

Jurić, U. (2007). Školsko (formalno), neformalno i informalno obrazovanje. In V. Previšić, N. N. Šoljan \& N. Hrvatić (eds.), Pedagogija prema cjeloživotnom obrazovanju i društvu znanja (p. 68 - 80). Zagreb: Hrvatsko pedagogijsko društvo.

Kerovec N. (1997). Stručno obrazovanje u funkciji zapošljavanja. Revija za socijalnu politiku, 2(1), $27-41$. Marković, D. (2005). Šta je neformalno u neformalnom obrazovanju? Neformalno obrazovanje u Evropi. Beograd: Grupa“Hajde da...".

Memorandum on Life Long Learning. (2000). Retrieved from http://www.hzpou.hr/stranice/3/21-100.pdf. Mialaret, G. (1989). Uvod u edukacijske znanosti. Zagreb: Školske novine.

Peko, A. (1999). Obrazovanje. In A. Mijatović, H. Vrgoč, A. Peko, A. Mrkonjić \& J. Ledić (eds.), Osnove suvremene pedagogije (pp. 203 - 223). Zagreb: Hrvatsko pedagoško-književni zbor.

Previšić, V. (2007). Prema cjeloživotnom obrazovanju i društvu znanja. Pedagogijska istraživanja, 4(2), $179-187$.

Razvoj politike cjeloživotnog profesionalnog usmjeravanja: Pojmovnik (2013). Sveučilište Jyväskylä: Europska mreža politika cjeloživotnog profesionalnog usmjeravanja. Retrieved from http://www. elgpn.eu/publications/browse-by-language/croatian/HR_glossary_web.pdf/.

Studija - Tržište rada i zapošljavanje (2003). Podgorica: Zavod za zapošljavanje Crne Gore.

Vrcelj, S. (2007). Traganja za drugačijim obrazovanjem - ima li nade? In V. Previšić, N. N. Šoljan \& N. Hrvatić (eds.), Pedagogija prema cjeloživotnom obrazovanju i društvu znanja (p. 477 - 488). Zagreb: Hrvatsko pedagogijsko društvo.

Žiljak, T. (2005). Politike cjeloživotnog učenja u Europskoj uniji i Hrvatskoj. Anali Hrvatskog političkog društva, 1(1), 225-243. 